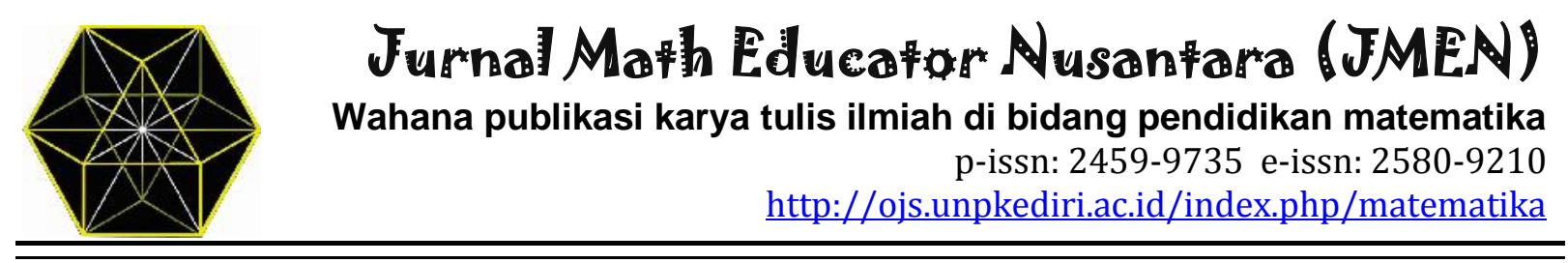

\title{
Meningkatkan Hasil Belajar Materi Garis dan Sudut Dengan Pendekatan Aktivitas Pada Siswa Kelas VII Semester 2 SMP Negeri 1 Ngantru Tulungagung
}

\author{
Bagus Nirwono \\ Guru matematika SMPN 1 Ngantru Kecamatan Ngantru Kabupaten Tulungagung \\ E-mail: nirwonob@gmail.com
}

Article received : 07 April 2018, article revised : 24 Mei 2018, article published: 30 Mei 2018

\begin{abstract}
Abstrak: Terwujudnya kondisi pembelajaran siswa aktif merupakan harapan dari semua komponen pendidikan termasuk masyarakat dan praktisi pendidikan. Oleh sebab itu dalam kegiatan pembelajaran dituntut satu stategi pembelajaran yang direncanakan oleh guru dengan mengedepankan keaktifan siswa dalam kegiatan belajar mengajar. Melalui kegiatan belajar yang menekankan pada aktivitas siswa diharapkan mampu meningkatkan motivasi dan hasil belajar yang sesuai dengan tujuan pendidikan di sekolah.

Ada beberapa jenis aktivitas yang disampaikan oleh para ahli, diantaranya: (1) kegiatan-kegiatan visual, (2) kegiatan-kegiatan lisan (oral), (3) mendengarkan, (4) menulis, (5) menggambar, (6) metric, (7) mental, dan (8) emosional. Paparan data data dalam pembahasan penelitian tindakan (action research) ini pada dasarnya menjabarkan tentang upaya peningkatan aktivitas belajar siswa dalam kegiatab belajar melalui kegiatan pembelajaran berbasis aktivitas. Ada beberapa hal cara meningkatkan keterlibatan siswa dalam upaya meningkatkan aktivitas belajar, diantaranya: (1) guru diharapkan dapat mengenal dan membantu anak-anak yang kurang terlibat. Selidiki apa yang menyebabkannya dan usaha apa yang bisa dilakukan untuk meningkatkan partisipasi anak tersebut, (2)guru harus menyiapkan mental dan kemandirian belajar siswa secara tepat, dan (3) sesuaikan pengajaran dengan kebutuhan-kebutuhan individual siswa.

Hasil penelitian dapat disimpulkan bahwa guru dalam upayanya meningkatkan hasil belajar siswa dengan menggunakan pendekatan pembelajaran berbasis aktifitas berhasil. Keberhasilan bisa diamati dari jumlah ketuntasan belajar individu siswa (nilai $\geq 75$ ) dengan ketuntasan kelas rata-rata $86,2 \%$,rata-rata nilai siswa 83,3,dan terjadi peningkatan 31 \% dari tahun pelajaran 2015-2016 dengan kategori tindakan cukup baik setelah menuntaskan siklus kedua.
\end{abstract}

Kata Kunci: Aktivitas, hasil belajar garis dan sudut, kelas VII SMP

\section{PENDAHULUAN}

Matematika sudah lama menjadi momok bagi kebanyakan siswa. Hal ini dapat diidentifikasi dari pendapat negatif kebanyakan siswa. Keadaan ini membuat kebanyakan siswa mudah menyerah belajar matematika apalagi ada pendapat yang mengatakan bahwa tidak bisa matematika itu wajar karena memang sulit. Temannya banyak dan sebagainya. Halnya dengan siswa kelas VII F SMPN 1 Ngantru pada tahun pelajaran 2015-2016 mempunyai nilai rata-rata 62,5 dengan ketuntasan klasikal mencapai 55,2 \% pada materi garis dan sudut jauh dari KKM yang telah ditentukan yaitu 75 dengan ketuntasan klasikal 85\%

Untuk mengatasi masalah diatas, guru harus mengambil langkah bijaksana. Berdasar diskusi dengan teman sejawat maka diperoleh beberapa solusi.Salah satu langkah yang ditempuh adalah pembelajaran aktif. Menurut Suparno, dkk (2002) siswa yang aktif dalam proses pembelajaran dicirikan oleh dua aktivitas, yaitu aktivitas dalam berpikir (minds-on), dan aktivitas dalam berbuat (hands-on). Perbuatan nyata siswa dalam pembelajaran merupakan hasil keterlibatan berpikir siswa terhadap kegiatan belajarnya. Dengan demikian 
proses siswa aktif dalam kegiatan belajar mengajar merupakan suatu kegiatan pembelajaran yang harus dilaksanakan secara terus menerus dan tiada henti. Hal ini dapat dilakukan apabila interaksi antara guru dan siswa terjalin dengan baik. Sebab menurut Usman (2002) interaksi dan hubungan timbal balik antara guru dan siswa itu merupakan syarat utama bagi berlangsungnya proses belajar mengajar.

Dalam aktivitas pembelajaran di sekolah, guru harus mengusahakan agar siswa dapat melakukan pengamatan yang efektif agar memperoleh hasil pembelajaran yang sebaikbaiknya. Dalam mengajar, hendaknya memberikan kesempatan kepada siswa untuk melakukan pengamatan yang sebaik-baiknya. Beberapa hal yang dapat dilakukan guru untuk membantu siswa melakukan pengamatan yang baik dalam pembelajaran adalah sebagai berikut: (a) Pengamatan akan lebih efektif kepada rangsangan-rangsangan yang mempunyai struktur dan bentuk yang jelas. Oleh karena itu, hal-hal yang akan dipelajari hendaknya mempunyai struktur dan organisasi yang jelas.

a. Pengamatan kepada sesuatu yang dekat akan lebih berkesan. Oleh karena itu, siswa diberi banyak kesempatan untuk lebih dekat dengan hal-hal yang akan dipelajari.

b. waktu guru mengajar, sebaiknya dimulai dengan pengalaman-pengalaman siswa.

c. Pengamatan dimulai dengan keseluruhan, baru kemudian kepada bagian-bagian. Oleh karena itu dalam memberikan bahan yang akan diajarkan, sebaiknya dimulai dengan keseluruhan, baru kemudian kepada bagian-bagian yang lebih khusus.

d. Pengamatan dipengaruhi oleh peringkat perkembangan individu. Oleh karena itu, pengajaran hendaknya disesuaikan dengan peringkat perkembangan individu, terutama peringkat perkembangan kognitif.

e. Terdapat perbedaan individual dalam pengamatan. Tiap individu mempunyai macam gaya pengamatan (ada gaya visual, auditif, taktis, dan kinestetik). Oleh karena itu pembelajaran hendaknya disesuaikan dengan gaya pengamatan masing-masing siswa.

Beberapa faktor dapat menimbulkan terjadinya kesalahan atau kelainan pengamatan, seperti rangsangan yang kurang jelas, kurangnya perhatian siswa, pengalaman di masa lampau, kurang baiknya alat indera, lingkungan yang mengganggu, dan sebagainya.

Menurut Hamalik (2001) mengatakan bahwa pengajaran yang efektif adalah pengajaran yang menyediakan kesempatan belajar sendiri atau melakukan aktivitas sendiri. Dalam kemajuan metodologi dewasa ini asas aktivitas lebih ditonjolkan melalui suatu program unit activity, sehingga kegiatan belajar siswa menjadi dasar untuk mencapai tujuan dan hasil belajar yang lebih memadai.

Ada beberapa jenis aktivitas yang disampaikan oleh para ahli, diantaranya: (1) kegiatan-kegiatan visual, (2) kegiatan-kegiatan lisan (oral), (3) mendengarkan, (4) menulis, (5) menggambar, (6) metrik, (7) mental, dan (8) emosional.(Hamalik : 2001)

Dari beberapa macam aktivitas tersebut menunjukkan bahwa dalam kegiatan pembelajaran, aktivitas siswa sangat diperlukan dalam memenuhi tujuan pembelajaran. Sehingga dalam suatu kegiatan pembelajaran, aktivitas siswa harus disesuaikan dengan materi pembelajaran yang disampaikan oleh guru atau masalah yang sedang dibahas. 
Kurikulum Matematika harus memberikan pengalaman belajar yang melibatkan siswa pada proses dan produk dalam ilmu pengetahuan dan teknologi. Pendekatan yang dipakai dalam kurikulum diharapkan akan mendorong siswa menjadi pelajar yang aktif dan fleksibel. Secara khusus pendekatan ini akan: (1) memperhatikan pcrbedaan individu siswa, (2) memberikan kesempatan yang sama kepada semua siswa imtuk mempelajari konsep-konsep esensial, (3) membekali siswa dengan ketrampilan untuk memahami dunia melalui penyelidikan, dan (4) membekali siswa dengan ketrampilan baik untuk memilih alat-alat yang sesuai maupun bahan-bahan yang diperlukan.

Kurikulum Matematika perlu memberikan pengalaman belajar yang membantu siswa memenuhi kebutuhan pribadi, sosial, lingkungan dan ekonomi. Standar kompetensi (SK) dalam pembelajaran materi dan sudut kelas VII SMP adalah Geometri (5) memahami hubungan garis dengan garis, garis dengan sudut, sudut dengan sudut serta menentukan ukurannya. Yang menjadi Kompetensi dasar (KD) adalah : (1) Menentukan hubungan antara dua garis ,serta besar dan jenis sudut.(2) Memahami sifat-sifat sudut yang terbentuk jika dua garis berpotongan atau dua garis sejajar berpotongan dengan garis lain.(3) Melukis sudut (4) Membagi sudut. Kegiatan pembelajaran sesuai KD 5.1 adalah (a) kedudukan dua garis seperti sejajar,berimpit,berpotongan dan bersilangan (b) satuan sudut yang sering digunakan seperti derajat dan radian. (c) pengukuran sudut dengan busur derajat (d) jenis-jenis sudut seperti sudut lancip,siku-siku dan tumpul. Kegiatan pembelajaran sesuai KD 5.2 adalah (a) sifat sudut akibat perpotongan dua garis (b) sifat sudut akibat perpotongan dua garis sejajar dengan sebuah garis. (c) Menyelesaikan soal yang berhubungan dengan sifat sudut. Kegiatan pembelajaran sesuai KD 5.3 adalah (a) Melukis sudut dengan penggaris dan busur derajat (b) Memindahkan sudut dengan penggaris dan jangka (c) Menggunakan jangka dan penggaris melukis sudut 60 dan90 (d) melukis sudut siku-siku dengan sepasang penggaris berbentuk segitiga. Kegiatan pembelajaran sesuai KD 5.4 adalah (a) Membagi sudut menjadi dua sama besar deengan penggaris dan jangka (b) Menggunakan penggaris dan jangka untuk melukis sudut 30, 45, 120 dan 150 .

Berdasarkan pada pendapat diatas menunjukkan bahwa aktifitas siswa dalam kegiatan belajar mengajar mutlak diperlukan. Namun yang lebih penting lagi dalam meningkatkan aktivitas siswa tersebut adalah kemampuan guru dalam merencanakan suatu kegiatan belajar mengajar tersebut dalam mencapai tujuan pembelajaran. : "Jika pendekatan pembelajaran yang selama ini digunakan guru mata pelajaran Matematika dalam materi garis dan sudut, diganti dengan pendekatan pembelajaran berbasis aktivitas, maka dimungkinkan akan terjadi peningkatan prestasi belajar siswa pada materi itu".

Penelitian tindakan kelas ini bertujuan untuk mengetahui dan mendeskripsikan (1) Pengaruh penggunaan pendekatan aktivitas dalam pembelajaran garis dan sudut terhadap motivasi belajar siswa (2) pengaruh penggunaan pendekatan berbasis aktivitas dalam pembelajaran garis dan sudut terhadap prestasi belajar siswa. Sedangkan penelitian memberi manfaat antara lain (1) Mengembangkan kemampuan profesi dan meningkatkan ketrampilan dalam proses pembelajaran oleh guru (2) mengembangkan proses pembelajaran agar lebih 
aktif, kreatif, dan menyenangkan (bermakna) bagi siswa (3) Bagi sekolah untuk peningkatan proses dan hasil pembelajaran.

\section{METODE}

Dalam penelitian ini digunakan jenis studi kasus. Alasan pemilihan karena berusaha meneliti pengaruh (refleksi) suatu tindakan yang diberikan pada unit sosial secara mendalam. Masalah yang dijadikan penekanan adalah bagaimana perilaku siswa bisa terpengaruh oleh proses pembelajaran yang menggunakan pendekatan aktifitas sehingga prestasi belajarnya meningkat atau belajarnya tuntas. Supaya diperoleh gambaran yang jelas dan mengenai sasaran maka data diambil dari satu obyek saja kemudian di teliti lebih mendalam.

Yang digunakan sebagai subyek penelitian adalah siswa kelas VII-A SMPN 1 Ngantru Tulungagung Jawa Timur pada semester genap tahun pelajaran 2016-2017 yang memiliki kemampuan heterogen.

Penelitian yang dilakukan meliputi tiga tahapan yaitu (1) tahap persiapan, (2) tahap pelaksanaan, (3) tahap pelaporan. Pada tahap pelaksanaan terbagi atas 3 siklus. Pengumpulan data yang digunakan dalam penelitian ini adalah (1) observasi, (2) wawancara, (3) angket, (4) dokumentasi. Untuk memperoleh keabsakan temuan, peneliti menggunakan tehnik trianggulasi yaitu menguji kebenaran data tertentu dengan membandingkannya dengan data yang diperoleh dari sumber lain, pada berbagai fase penelitian lapangan, pada waktu yang berlainan dan sering menggunakan metode yang berlainan. Pada penelitian ini analisa data dilakukan terus menerus, mulai siklus tindakan awal sampai siklus tindakan terakhir. Tehnik analisa data yang digunakan adalah (1) reduksi data, (2) display, (3) kesimpulan dan verifikasi.

Skor hasil tes siswa dalam mengerjakan soal-soal yang meliputi skor hasil tes pengetahuan prasyarat yang diberikan sebelum tindakan, hasil tes pada setiap akhir tindakan, dan hasil pekerjaan siswa dalam kegiatan pembelajaran. Hasil pekerjaan tersebut akan digunakan unuk melihat peningkatan pemahaman dan pen capaian hasil belajar siswa. satu Presentase ketuntasan individual (Agustina dalam tim STKIP : 2007) adalah perbandingan jumlah skor yang dicapai siswa dengan skor maksimum/ideal dikalikan seratus persen.Siswa dianggap tuntas secara individu, jika ketuntasan yang dicapai minimal 75\% (Kriteria Ketuntasan Minimal atau KKM ) .Persentase ketuntasan kelas (Agustina dalam Tim STKIP: 2007) adalah perbandingan jumlah siswa yang tuntas dengan jumlah siswa dikalikan seratus persen.Kelas/Klasikal dianggap tuntas jika mencapai $85 \%$.

Kriteria taraf keberhasilan tindakan (Suharsimi dalam tim STKIP:2007 ) dapat ditentukan sebagai berikut :

$$
\begin{aligned}
& 75 \%<\text { NR }<100 \% \text { : Sangat Baik } \quad 25 \%<N R<50 \% \text { : Cukup Baik } \\
& 50 \%<N R<75 \% \text { : Baik } \quad 0 \%<N R<25 \% \text { : Kurang Baik }
\end{aligned}
$$




\section{HASIL DAN PEMBAHASAN (70\%)}

\section{Hasil Penelitian}

Siklus 1

Paparan data dalam pembahasan penelitian tindakan (action research) ini pada dasarnya menjabarkan tentang upaya peningkatan prestasi belajar siswa melalui kegiatan pembelajaran berbasis aktivitas. Kedatangan guru ke kekelas mendapati (1) Kesiapan pembelajaran pendidik baik dan peserta didik cukup (2) Seting pembelajaran baik (3) Penampilan pendidik baik, penampilan peserta dan lingkungan sedang serta usaha pendidik memperbaiki peserta dan lingkungan baik (4) Kegiatan membuka pembelajaran baik (5) Kegiatan inti pembelajaran sedang (6) Kegiatan menutup pembelajaran sedang (7) Pengalaman pembelajaran bagi pendidik baik bagi peserta sedang

Kegiatan pembelajaran sesuai KD 5.1 adalah (a) kedudukan dua garis seperti sejajar, berimpit,berpotongan dan bersilangan (b) satuan sudut yang sering digunakan seperti derajat dan radian. (c) pengukuran sudut dengan busur derajat (d) jenis-jenis sudut seperti sudut lancip,siku-siku dan tumpul.Kegiatan pembelajaran sesuai KD 5.2 adalah (a) sifat sudut akibat perpotongan dua garis (b) sifat sudut akibat perpotongan dua garis sejajar dengan sebuah garis. (c) Menyelesaikan soal yang berhubungan dengan sifat sudut.

Selanjutnya untuk membuktikan keefektifan penggunaan pembelajaran berbasis aktivitas dalam kegiatan belajar mengajar, selanjutnya strategi pembelajaran ini ditindaklanjuti pada kegiatan siklus berikutnya

Siklus 2

Kegiatan pada siklus 2, pada dasarnya sama dengan apa yang dilakukan oleh peneliti dalam kegiatan belajar mengajar yang dilakukan pada siklus 1 ini, yaitu dilaksanakan selama dua kali pertemuan masing-masing pertemuan $2 \times 40$ menit. Ada pun hasil dan kegiatan belajar mengajar pada kegiatan siklus 2 ini, secara rinci akan dipaparkan sebagai berikut di bawah ini.(1).Kesiapan pembelajaran pendidik baik dan peserta didik baik (2).Seting pembelajaran baik(3).Penampilan pendidik baik, penampilan peserta dan lingkungan sedang serta usaha pendidik memperbaiki peserta dan lingkungan baik (4).Kegiatan membuka pembelajaran baik (5).Kegiatan inti pembelajaran baik (6).Kegiatan menutup pembelajaran baik (7). Pengalaman pembelajaran bagi pendidik baik bagi peserta baik (8).

Kegiatan pembelajaran sesuai KD 5.3 adalah (a) Melukis sudut dengan penggaris dan busur derajat (b) Memindahkan sudut dengan penggaris dan jangka (c) Menggunakan jangka dan penggaris melukis sudut 60 dan90 (d) melukis sudut siku-siku dengan sepasang penggaris berbentuk segitiga.Kegiatan pembelajaran sesuai KD 5.4 adalah (a) Membagi sudut menjadi dua sama besar deengan penggaris dan jangka (b) Menggunakan penggaris dan jangka untuk melukis sudut 30, 45, 120 dan 150. 
Tabel 1 : Hasil penilaian tes siklus 1 dan 2

\begin{tabular}{|c|c|c|c|c|c|}
\hline NO & Rentang Nilai & $\begin{array}{l}\text { Frekwensi } \\
\text { Siklus } 1\end{array}$ & $\begin{array}{l}\text { Frekwensi } \\
\text { siklus } 2\end{array}$ & $\begin{array}{l}\text { Kategori } \\
\text { Prestasi Belajar }\end{array}$ & Keterangan \\
\hline 1. & $95 \leq \mathrm{N} \leq 100$ & 1 & 2 & Sangat Baik & Naik 1 \\
\hline 2 & $85 \leq N \leq 94$ & 11 & 13 & Baik & Naik 2 \\
\hline 3 & $75 \leq N \leq 84$ & 17 & 18 & sedang & Naik 1 \\
\hline 4 & $65 \leq N \leq 74$ & 4 & 2 & Cukup baik & Naik 2 \\
\hline 5 & $55 \leq N \leq 64$ & 2 & 1 & kurang & Naik 1 \\
\hline 6 & $N \leq 54$ & 1 & 0 & Kurang sekali & Naik 1 \\
\hline Total: & & 36 & 36 & & Naik 8 \\
\hline
\end{tabular}

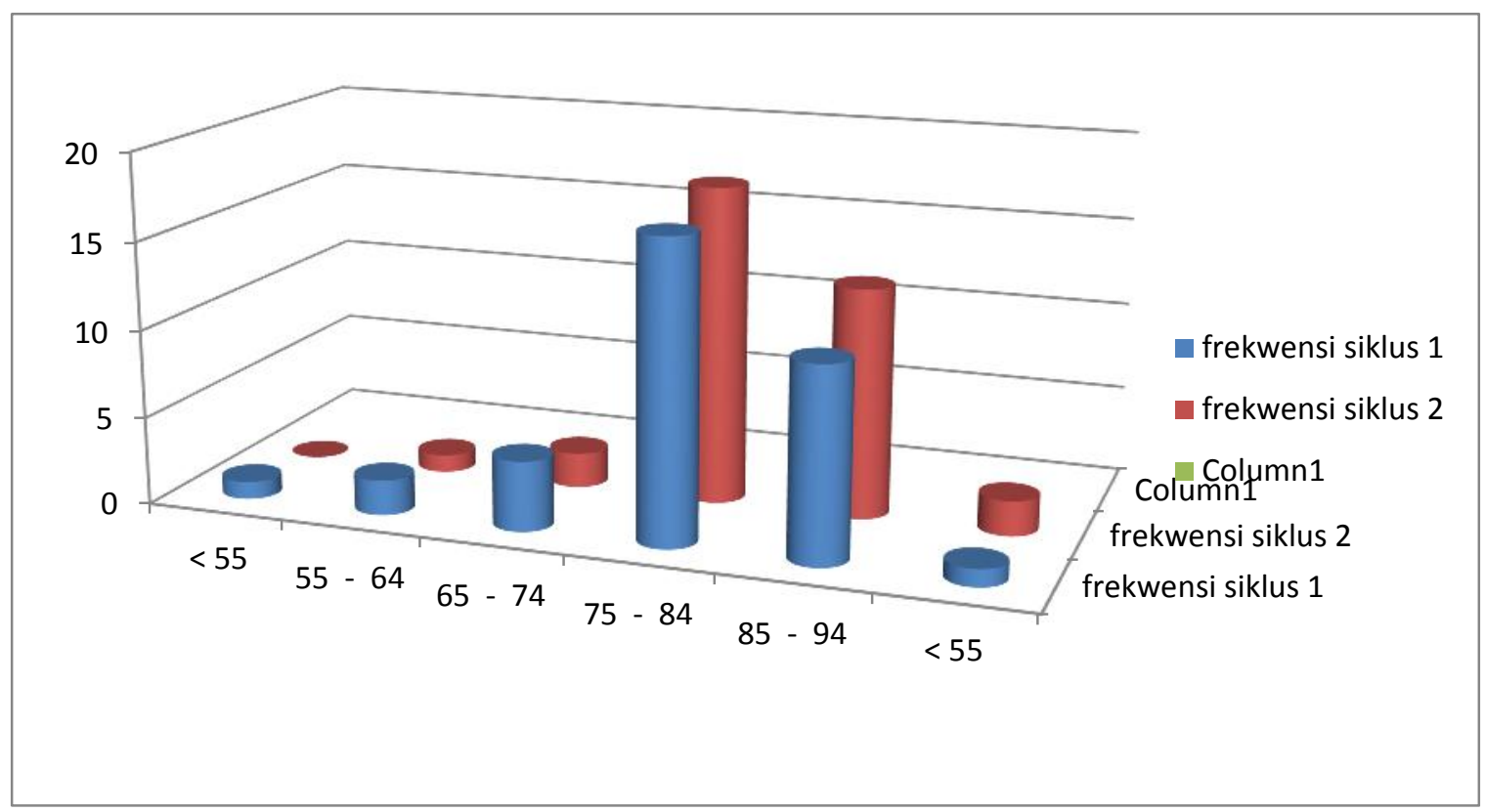

Presentase ketuntasan individual diperoleh dari jumlah nilai yang diperoleh siswa dibagi nilai ideal.Siswa dianggap tuntas secara individu, jika skor yang dicapai minimal 75 ( Kriteria Ketuntasan Minimal atau KKM ) .Ketuntasan individu setelah siklus 1 adalah 29 dari 36 siswa atau 80,5\% dengan nilai rata-rata 80,4 .Sedangkan ketuntasan individu setelah siklus 2 adalah 35 dari 36 siswa atau $92 \%$ dengan nilai rata-rata 83,3.Nilai rata-rata individu siklus 1 dan 2 adalah 81,9.Terjadi peningkatan rata-rata nilai yang diperoleh siswa pada pembelajaran materi garis dan sudut dari tahun pelajaran 2015-2016 yang sebesar 62,5 menjadi 81,9 atau 19,4 hasil pendekatan pembelajaran aktivitas pada tahun pelajaran 2016-2017.Peningkatan 19,4 atau $31 \%$ dari 62,5 menurut Suharsimi (dalam Tim STKIP:2007) termasuk dalam taraf keberhasilan tindakan yang cukup baik.

Presentase ketuntasan kelas/klasikal diperoleh dari jumlah siswa yang tuntas dibagi jumlah siswa. Ketuntasan klasikal dapat tercapai jika jumlah siswa yang tuntas mencapai 
minimal $85 \%$ dari jumlah siswa keseluruhan di suatu kelas. Ketuntasan kelas rata-rata hasil penilaian proses siklus 1 dan 2 adalah 86,3\%. Terjadi peningkatan ketuntasan kelas pembelajaran materi garis dan sudut dari tahun pelajaran 2015-2016 yang sebesar 55,2\% menjadi $86,3 \%$ atau $30,9 \%$ hasil pendekatan pembelajaran aktivitas pada tahun pelajaran 2016-2017.Menurut Suharsimi dalam Tim STKIP:2007) termasuk dalam taraf keberhasilan tindakan yang cukup baik.

Hasil penilaian proses menunjukan bahwa 8 dari 36 siswa mengalami kenaikan dari siklus 1 ke siklus 2 atau 22,2 \%.Menurut Suharsimi (dalam Tim STKIP:2007)termasuk dalam taraf keberhasilan tindakan yangkurang baik.

Tabel 2 : Rekapitulasi angket motivasi pengaruh dari Pendekatan Pembelajaran Berbasis Aktivitas Pada materi Garis Dan Sudut

\begin{tabular}{|c|c|c|c|c|c|c|c|c|}
\hline \multirow{3}{*}{$\begin{array}{l}\text { No } \\
\text { Ang } \\
\text { ket }\end{array}$} & \multirow{3}{*}{ Kriteria Yang Diukur } & \multicolumn{7}{|c|}{ pendapat } \\
\hline & & \multicolumn{3}{|c|}{ Sebelum siklus 1} & \multicolumn{3}{|c|}{ Sesudah siklus 2} & \multirow{2}{*}{$\begin{array}{l}\text { Keteran } \\
\text { gan skor }\end{array}$} \\
\hline & & Ya & Tdk & Skor & Ya & Tdk & Skor & \\
\hline \multirow[t]{2}{*}{1} & Senang belajar & 14 & 22 & 1,39 & 26 & 10 & 1,72 & Naik \\
\hline & & & & & & & & $33 \%$ \\
\hline \multirow[t]{2}{*}{2} & Mudah memahami materi & 15 & 21 & 1,50 & 22 & 14 & 1,61 & Naik \\
\hline & pelajaran & & & & & & & $21 \%$ \\
\hline \multirow[t]{2}{*}{3} & Termotivasi untuk belajar & 16 & 20 & 1,44 & 26 & 10 & 1,72 & Naik \\
\hline & & & & & & & & $28 \%$ \\
\hline \multirow[t]{2}{*}{4} & Meningkatkan kemampuan & 10 & 26 & 1,28 & 19 & 17 & 1,53 & Naik \\
\hline & berpikir tingkat tinggi & & & & & & & $25 \%$ \\
\hline \multirow[t]{4}{*}{5} & menyampaikan & 12 & 24 & 1,33 & 25 & 11 & 1,81 & Naik \\
\hline & pendapat & & & & & & & $48 \%$ \\
\hline & Rata-rata & 13,4 & 22,6 & 1,37 & 23,6 & 13,4 & 1,68 & Naik \\
\hline & & & & & & & & $31 \%$ \\
\hline
\end{tabular}




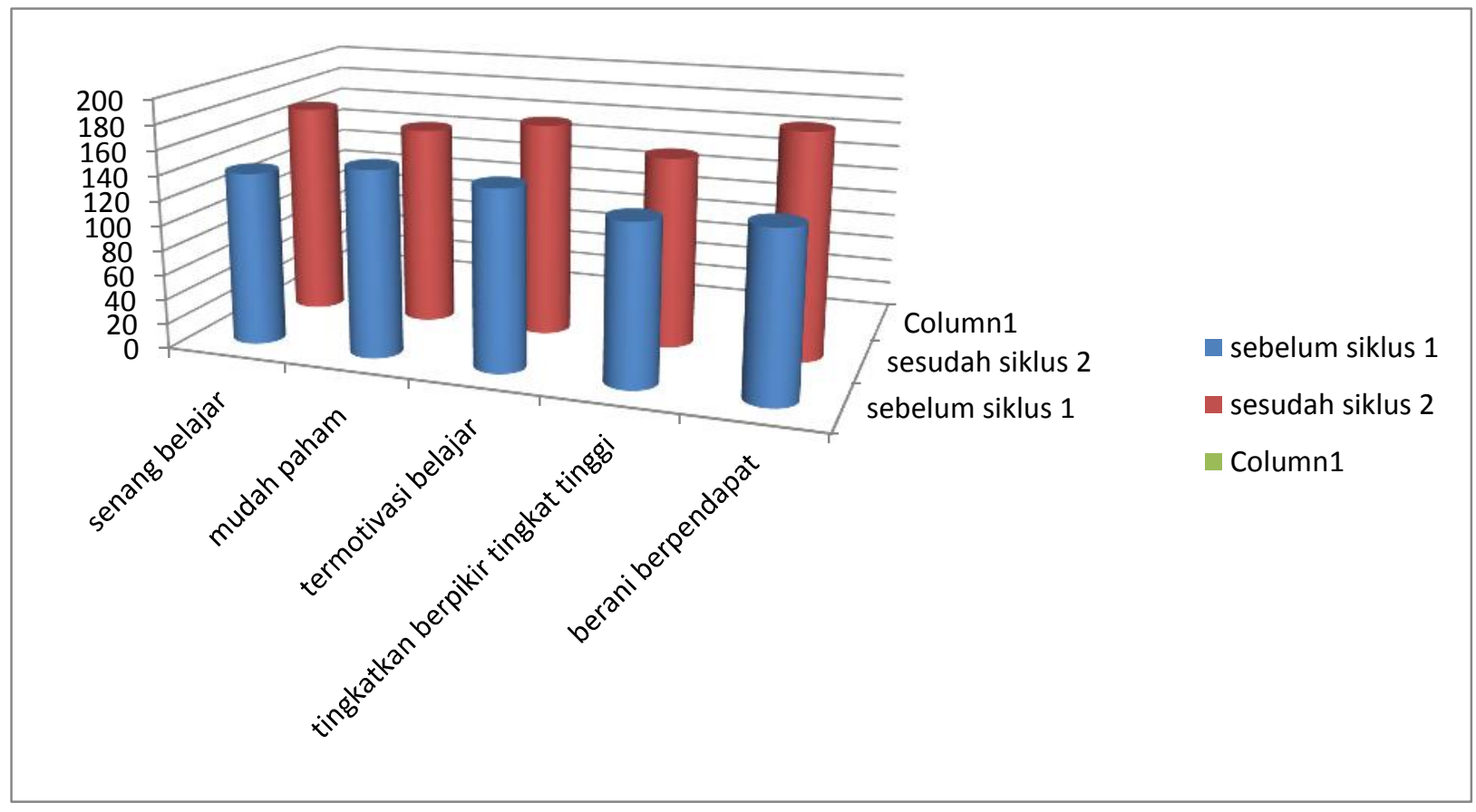

Berdasarkan pada akhir kegiatan siklus 2 tersebut; peneliti meiakukan refleksi dari hasil kegiatan penelitian sebagai berikut: (1) terlihat ada peningkatan motivasi siswa dalam mengikuti kegiatan belajar mengajar dibandingkan dengan kegiatan belajar mengajar sebelumnya (menggunakan strategi tradisional), (2) beberapa siswa cepat dalam mempelajari materi yang disampaikan oleh guru, (3) beberapa siswa sudah ada keberanian dalam menyampaikan pendapat, dan (4) kegiatan diskusi sudah terkesan hidup dan berjalan, tidak lagi didominasi oleh siswa yang pandai.

Berdasarkan data pengamatan dan obeservasi peneliti selama kegiatan penelitian tindakan, dapat diperoleh data aktivitas siswa dalam kegiatan belajar mengajar siswa bahwa aktivitas siswa dalam kegiatan belajar dengan pendekatan berbasis aktivitas menunjukkan ada peningkatan dibandingkan dengan strategi yang digunakan oleh guru sebelumnya. Hal ini dapat dilihat data yang didapatkan oleh peneliti dan hasil belajar siswa dalam kegiatan belajar mengajar, menunjukkan motivasi belajar siswa mulai meningkat.

\section{SIMPULAN}

Berdasarkan temuan dan pembahasan dapat ditarik kesimpulan sebagai berikut (1) Pendekatan aktivitas membuat siswa aktif dalam belajar. (2) Pendekatan Pembelajaran Berbasis Aktivitas dapat meningkatkan prestasi belajar siswa pada materi garis dan sudut Untuk memaksimalkan hasil belajar, pembelajaran tentang teorema geometri bagi siswa SMP sebaiknya mempertimbangkan cara pandang dan hasil penelitian ini. 


\section{DAFTAR PUSTAKA}

Hamalik, O: 2001. Proses Belajar Mengajar. Jakarta : PT. Bumi Aksara

Hamalik, O: 2002. Perencanaan Pengajaran Berdasarkan Pendekatan Sistem. Jakarta: PT. Bumi Aksara

Lampiran Peraturan Menteri Pendidikan no 22 Tahun 2006. Tentang Standar Isi

Lampiran Peraturan Menteri Pendidikan no 23 Tahun 2006. Tentang Standar Kompetensi Lulusan

Lampiran Peraturan Menteri Pendidikan no 41 Tahun 2007. Tentang Standar Proses

Materi Pelatihan Terintegrasi,Buku 1 :Jakarta.Depdiknas.Dirjen Dikdasmen,Direktorat pembinaan SMP.

Materi Pelatihan Terintegrasi,Buku 2 :Jakarta.Depdiknas.Dirjen Dikdasmen,Direktorat pembinaan SMP.

Materi Pelatihan Terintegrasi,Buku 3 :Jakarta.Depdiknas.Dirjen Dikdasmen,Direktorat pembinaan SMP.

Suparno, P., Rohandi, R., Sukadi, G., Kartono, S: 2001. Reformasi Pendidikan Sebuah Rekomendasi Yogyakarta: Penerbit Kanisius.

Tim STKIP PGRI Tulungagung : 2007.Makalah Penelitian Tindakan Kelas (Action Reseac).Seminar Menjadi Guru Profesional.

Usman, Uzer, M : 2002. Menjadi Guru Profesional. Edisi Kedua. Cetakan ke empat belas. Bandung : PT Remaja Rosdakarya.

Wilis,D,Ratna : 1988.Teori-teori Belajar.Jakarta.P2LPTK

Zuriah, N.: 2003. Penelitian Tindakan dalam bidang Pendidikan dan Sosial. Edisi Pertama. Malang: Bayu Media Publishing. 